\title{
State Capital Taxes and the Location of Investment: Empirical Lessons from Theoretical Models of Tax Competition
}

\author{
Brian Knight* \\ Board of Governors of the Federal Reserve System \\ Washington, D.C. 20551 \\ e-mail: bknight@frb.gov
}

December 2002

\begin{abstract}
Applying insights from theoretical tax competition models, this study of manufacturing investment and taxes in U.S. states makes four contributions to the empirical tax competition literature. First, while the existing empirical literature has assumed exogenous tax rates, the theoretical model, which endogenizes state tax rate choices, demonstrates that tax rates and investment decisions are determined by the same set of jurisdiction characteristics. The endogeneity corrected estimates, which rely on instruments motivated by the theoretical model, suggest stronger responses to tax rates than the uncorrected estimates in both this paper and the existing literature. The second insight involves the appropriate unit of observation. The empirical literature has conducted both aggregate analyses, in which jurisdictions are the unit of observation, and discrete choice analyses, in which manufacturing plants are the unit of observation. While the tax competition model demonstrates the violation of a key assumption in discrete choice analyses, the estimating equation in this paper, an aggregate analysis, can be derived directly from the model. Third, the theoretical model sheds light on the appropriateness of previously employed measures of tax burdens. The effective tax rate is shown to be superior to the after-tax rate of return, which is both invariant across jurisdictions and dependent on the distribution of investment. Fourth, this paper provides estimates of the degree of undertaxation of capital, which has been the focus of the theoretical tax competition literature but has yet to be addressed empirically. These estimates suggest that the efficient revenues may be as much as two times the size of actual revenues.
\end{abstract}

${ }^{*}$ The views presented are solely those of the author and do not necessarily represent those of the Federal Reserve Board or its staff. Thanks to Darrel Cohen, Kelly Edmiston, Phil Haile, Bob Haveman, Arik Levinson, and Andrew Reschovsky for helpful comments. 


\section{Introduction}

Policymakers have long debated the proper vertical assignment of taxation powers within a federation. Recently, many have argued that the taxation of mobile factors, such as capital, may best be left to centralized governments if subnational governments underprovide public services when competing for this tax base. In the United States, policymakers have expressed concern that state and local governments underprovide public services in a "race to the bottom" when competing for mobile capital. In the European Union, countries with high tax rates on capital have called for harmonized tax rates to mitigate the outflow of investment to low-tax countries.

These arguments for centralized taxation by policymakers have been mirrored in the economics literature. Oates (1972) Decentralization Theorem first pointed out the welfare consequences of fiscal externalities, the effect of a jurisdiction's policies on the tax base of neighboring jurisdictions. While decentralized governments fail to account for these neighbor effects, central governments may better internalize such spillovers across jurisdictions. Several authors, including Zodrow and Mieszkowki (1986), Wilson (1986), and Wildasin (1989), have formalized these ideas in theoretical models of tax competition.

While the theoretical literature has examined these normative properties of tax competition, the empirical literature has focused almost exclusively on the positive aspects. This empirical literature employs variation in business tax burdens, typically across U.S. states, to measure the responsiveness of economic activity to these taxes. Commonly used measures of economic activity include manufacturing investment and employment. The survey by Bartik (1994) has suggested a relatively small elasticity, between 0.1 and 0.6 , of activity with respect to business taxes. ${ }^{1}$

While the theoretical and empirical literatures on tax competition have grown voluminous, there is little work attempting to integrate the two. This paper uses theoretical models of tax competition and an econometric analysis of manufacturing investment in U.S. states in order to make four contributions to the empirical literature. First, the model demonstrates that tax rates are endogenous since, through the competition for capital, state tax rates depend upon unobserved state characteristics. This endogeneity has biased existing elasticity estimates, which have typically assumed exogenous variation in tax burdens across jurisdictions. To correct for such endogeneity, the tax competition model motivates the use of instruments based upon state population, resident preferences for public goods, costs of providing public goods, and characteristics of neighboring, or competitor, states.

The second contribution involves the appropriate unit of observation. The empirical literature has conducted both aggregate analyses, in which jurisdictions are the unit of analysis, and discrete choice analyses, in which firms or manufacturing plants are the unit of observation. ${ }^{2}$ The tax competition model demonstrates that a key assumption

\footnotetext{
${ }^{1}$ For a complete review of this literature, see Bartik or Wasylenko (1997).

${ }^{2}$ Carlton (1983) provides a discrete choice analysis, while Papke (1991), Papke (1987), and Hines (1996) conduct aggregate analyses, although it should be noted that Papke (1991) uses underlying plant-level data.
} 
in empirical discrete choice analyses, independence of plant location choices, is violated. Due to fixed production factors, capital owners choosing to invest in a given jurisdiction lower the after-tax rate of return, providing incentives for other owners to invest elsewhere. On the other hand, the estimating equation typically used in empirical aggregate analyses can be derived directly from a no-arbitrage condition, or equalization of after-tax rates of return, in the theoretical tax competition model.

Regarding the third contribution, the theoretical literature informs as to the appropriate measure of tax burdens. Some empirical studies have used effective tax rates, while others, such as Papke (1991), have argued that the after-tax rate of return on investment is a superior measure. Although the after-tax rate of return does vary across industries, thereby providing an additional source of variation, and captures many otherwise hidden features of the tax code, the theoretical model analyzed in this paper demonstrates the superiority of the effective tax rate. In the model, investment shifts between jurisdictions until a no-arbitrage condition, equalization of after-tax rates of return, is satisfied. Thus, the model predicts that after-tax rates of return both do not vary across jurisdictions in equilibrium and are endogenous because they depend upon the distribution of investment across jurisdictions. By contrast, regressions using the effective tax rate are shown to provide consistent estimates of the elasticities of interest. To empirically implement this theoretical insight, measures of the effective tax rate are constructed based upon Wheaton (1983).

The fourth contribution involves the normative properties of tax competition, which have been ignored in the existing empirical literature (Oates, 1999). In the tax competition model analyzed in this paper, states set tax rates according to a modified Samuelson rule, and the degree of under-taxation is related to the elasticity of investment with respect to tax rates. Using estimates of this elasticity, and a convenient specification of resident utility functions, I calculate the revenue received by state governments under the efficient, Samuelson tax rates. A comparison of actual and Samuelson revenues provides an estimate of the degree of under-taxation by state governments.

\section{Theoretical Model}

The tax competition model presented here follows Zodrow and Mieszkowski (1986). ${ }^{3}$ In the model, capital owners choose to invest among $J$ jurisdictions, which will be referred to as a market for investment in the empirical analysis. These jurisdictions set tax rates on capital in order to maximize the welfare of a representative agent, who is assumed immobile across jurisdictions. The representative agent is endowed with labor and owns a fixed share of the national capital stock. This agent may costlessly invest his share of the capital stock in any jurisdiction and thus does not necessarily invest in the jurisdiction of residence. The returns to these factors, capital and labor, finance private consumption $(z)$. In addition, the representative agent gains utility from consuming a publicly provided good $(G)$, which is financed through the taxation of capital.

In order to produce the private good, perfectly competitive firms in each jurisdiction

\footnotetext{
${ }^{3}$ For a comprehensive review of the theoretical tax competition literature, see Wilson (1999).
} 
have access to a technology that exhibits constant returns to scale in capital and labor. That is, $Y=F(K, L)$, where $Y$ is output of the private good, $K$ is capital, and $L$ is labor. Since labor is assumed to be supplied inelastically, it is useful to express the technology in per-capita labor units, $y=f(k)$, where $y$ is output per worker and $k$ is the capital to labor ratio in the jurisdiction.

\subsection{Firm Location Choices}

Taking the actions of other capital owners as given, each chooses to invest in the jurisdiction that maximizes the after-tax return to capital:

$$
r=f_{k}-\tau
$$

where $f_{k}$ is the marginal product of capital, or pre-tax return, and $\tau$ is the unit tax rate on capital. Given that each investor is choosing a location in order to maximize its after-tax rate of return, a no arbitrage condition of equal rates of return for each jurisdiction must hold in equilibrium:

$$
f_{k}-\tau=f_{k}^{0}-\tau^{0}
$$

where $f_{k}^{0}-\tau^{0}$ represents the after-tax rate of return in a benchmark jurisdiction. This benchmark jurisdiction can be interpreted as either one of the $J$ jurisdictions or an "outside option" jurisdiction. This outside option could represent, for example, investing abroad or a decision to not invest.

\subsection{Tax Rate Choices}

Each jurisdiction is assumed to maximize the utility $U(z, G)$ of a representative agent, where $z$ is private consumption and $G$ is the level of the public good in the jurisdiction. In order to focus on tax externalities, I assume that there are no public good expenditure externalities across jurisdictions; thus, these are purely local public goods. The returns to labor $\left[f(k)-k f_{k}\right]$ and capital $[r \bar{K}]$, where $\bar{K}$ is the amount of capital owned by the representative agent, finance private consumption:

$$
z=f(k)-k f_{k}+r \bar{K}
$$

Following the literature on capital tax competition, jurisdictions are restricted from imposing lump-sum taxes on residents; rather, by assumption, public goods are financed exclusively through taxation of capital:

$$
c G=k L \tau
$$

where $c$ is the unit cost, assumed constant, of providing public goods, $k L$ is capital locating in the jurisdiction, and $\tau$ is the unit tax rate on capital.

Each jurisdiction is assumed sufficiently small as to take the after-tax rate of return $(r)$ as given. Under this assumption, the first order condition for the tax rate choice of each jurisdiction is given as follows: 


$$
\frac{\partial U}{\partial Z}\left[k f_{k k} \frac{\partial k}{\partial \tau}\right]=\frac{L}{c} \frac{\partial U}{\partial G}\left[k+\tau \frac{\partial k}{\partial \tau}\right]
$$

Equation (5) reflects the trade-off in setting tax rates between consumption of public and private goods. The left-hand side represents the effect of a tax rate increase on utility from private consumption. In the face of a tax increase, investment shifts out of the jurisdiction, resulting in decreased labor income and hence decreased private consumption. Thus, the left-hand side is positive. The right-hand side represents the effect of a tax rate increase on the utility from consuming public goods. When increasing the tax rate, additional revenue is collected from capital remaining in the jurisdiction $[k]$, but revenue is lost from investment shifting out of the jurisdiction $\left[\tau \frac{\partial k}{\partial \tau}\right]$. Thus, the total effect on the tax base and hence public good provision is ambiguous. However, at an optimum, the former effect, the collection of additional revenue, dominates since the right-hand side must be positive in equation (5). Thus, at an optimum, the downward portion of the Laffer curve is ruled out.

Next, differentiate the after-tax rate of return in equation (1) with respect to the tax rate:

$$
\frac{\partial r}{\partial \tau}=f_{k k} \frac{\partial k}{\partial \tau}-1
$$

Since jurisdictions take the after tax rate of return as given $\left[\frac{\partial r}{\partial \tau}=0\right]$, it follows that

$\frac{\partial k}{\partial \tau}=\frac{1}{f_{k k}}$. Substituting this expression into equation (5) and re-arranging yields a modified Samuelson condition:

$$
L \frac{\partial U / \partial G}{\partial U / \partial Z}=\frac{c}{1-\varepsilon}
$$

where $\varepsilon=\left|\frac{\partial k}{\partial \tau} \frac{\tau}{k}\right|$ represents the elasticity of capital stock with respect to the tax rate. As capital becomes more responsive to tax rates, this elasticity increases in absolute value and the competition becomes more intense, leading jurisdictions to undercut each other's rates. Regarding the welfare implications, tax rates are set too low and public goods are underprovided, relative to the Samuelson rule, which equates the sum of marginal rates of substitution to the marginal cost of public good provision (i.e. equation 7 with $\varepsilon=0)$.

\section{Empirical Model}

The no arbitrage condition in equation (2) forms the basis for an estimating equation. While the tax rate choice in equation (7) is not estimated explicitly, it will be employed in the empirical analysis in three ways: to demonstrate the endogeneity of tax rates, to suggest instruments to correct for such endogeneity, and, in conjunction with the estimates of the responsiveness of investment, to calculate the degree of undertaxation of capital. For estimation purposes, consider the following linear parameterization for the technology, or pre-tax returns to capital: 


$$
f_{k}=\alpha(\delta-k)
$$

where $\delta>0$ reflects the overall productivity of capital and $\alpha>0$ captures the possibility of diminishing returns to scale. ${ }^{4}$ Using this parameterization, the elasticity of capital with respect to tax rates $\left(\varepsilon=\frac{\tau}{\alpha k}\right)$ is decreasing in the parameter $\alpha$. This parameter $\alpha$ can be interpreted as a congestion effect, the reduction in pre-tax returns due to additional investment in the jurisdiction. As this congestion effect goes to zero, the production function approaches constant returns to scale, and investment becomes infinitely responsive to tax rates. In the extreme, with zero congestion effects, all capital owners invest in the jurisdiction with the lowest tax rate.

Next, allow for heterogeneity across jurisdictions $(j)$ and markets $(m)$ in the productivity parameter $\delta$.

$$
\delta_{j m}=\beta X_{j m}+\xi_{j m}
$$

where $X$ and $\xi$ represent observed and unobserved location characteristics, respectively. Inserting these parameterizations in equations (8) and (9) into the no-arbitrage condition, given by equation (2), yields the equation to be estimated:

$$
k_{j m}=-(1 / \alpha) \tau_{j m}+\beta X_{j m}+\lambda_{m}+\xi_{j m}
$$

where the market effect $\left[\lambda_{m}=k_{0 m}+(1 / \alpha) \tau_{0 m}-\beta X_{0 m}-\xi_{0 m}\right]$ is included in the regression as a simple market dummy variable. Thus, investment is decreasing in the jurisdiction's own tax rate $\left(\tau_{j m}\right)$, increasing in the outside option tax rate $\left((1 / \alpha) \tau_{0 m}\right)$, and increasing in the desirability of location characteristics, both observed $\left(\beta X_{j m}\right)$ and unobserved $\left(\xi_{j m}\right)$.

In the context of this empirical specification, the theoretical model with endogenous tax rates provides four insights for the empirical analysis. First, the modified Samuelson condition in equation (7) demonstrates that tax rates are endogenous since they are set by jurisdictions competing with each other for investment. That is, tax rates are correlated with unobserved location characteristics $\left(\xi_{j m}\right)$ through the elasticity of investment with respect to taxes $(\varepsilon)$, which is itself a function of location characteristics, both observed and unobserved. This correlation biases OLS estimates of equation (10). To correct for this bias, equation (7) provides a framework for selecting instruments. Public spending, and thus tax rates, depend upon four factors: state population $(L)$, preferences for public goods, as reflected in the marginal rate of substitution $\left(\frac{\partial U / \partial G}{\partial U / \partial Z}\right)$, costs of providing public goods $(c)$, and characteristics of other jurisdictions, which are reflected in the elasticity of investment with respect to tax rates $(\varepsilon)$. Each of these variables affect tax rates but are excluded from the structural equation (10) and are thus valid instruments.

The second insight involves the appropriate unit of observation. The existing empirical literature has employed both discrete choice models, where manufacturing plants, which can be interpreted as units of investment, are the unit of analysis, and aggregated

\footnotetext{
${ }^{4}$ Alternatively, one can express the equivalent quadratic production function $f(k)=\alpha\left(\delta k-\frac{1}{2} k^{2}\right)$.
} 
models, in which jurisdictions are the unit of analysis. In the former, plants locate in jurisdictions that maximize their after-tax rate of return. Since the after-tax rate of return in equation (1) depends upon total investment in the jurisdiction, a key assumption in discrete choice models, independence of location choices across plants, is violated. ${ }^{5}$ While the discrete choice framework is inconsistent with the theoretical model of tax competition, the estimating equation (10) was derived directly from the model. This estimating equation is similar to those employed in aggregate empirical analyses, although some have failed to include investment market dummy variables $\left(\lambda_{m}\right)$.

The third insight involves the appropriate measure of tax burdens. The existing empirical literature has employed measures of both effective tax rates and after tax rates of return. Although the after-tax rate of return does vary across industries, thereby providing an additional source of variation, and captures many otherwise hidden features of the tax code, equation (10) demonstrates that the effective tax rate is the appropriate right-hand side variable. After-tax rates of return do not vary across jurisdictions in the theoretical model. In the context of this theoretical tax competition model, empirical variation in rates of return across states may either reflect measurement error or simply provide evidence against the assumption of perfectly mobile capital. In either case, one should not interpret a negative correlation between after-tax rates of return and investment as evidence of responsiveness of economic activity to tax burdens. Further, even if after-tax rates of return were to vary across jurisdictions in the tax competition model, these rates are a function of investment, as demonstrated in equation (8), and are thus endogenous measures of tax burdens. By contrast, regressions using the effective tax rate provide consistent estimates of the elasticities of interest. To empirically implement this theoretical insight, measures of the effective tax rate are constructed based upon Wheaton (1983).

Fourth, while the existing empirical literature has focused on the positive issue of the responsiveness of investment to tax burdens, the theoretical literature has had a normative focus on the under-taxation of capital. With a parameterization for resident utility functions, elasticity estimates can be used to uncover the Samuelson revenues. A comparison of actual and Samuelson revenues will provide an estimate of the degree of undertaxation of capital. This issue will be explored in further detail in section 6 .

\section{Data}

To provide variation across markets $(m)$ for investment, I take a single year as the definition of a market. That is, I assume that states compete for investment in a static manner. The sample consists of 47 states across three markets $(1977,1982$, and 1987); these years correspond with Census of Manufacturing surveys. ${ }^{6}$ I exclude Alaska and Hawaii, since they are fiscal and geographic outliers. Since I use legislative party

\footnotetext{
${ }^{5}$ Of course, discrete choice models have the advantage of controlling for both observed and unobserved characteristics of plants. The tax competition model in this paper abstracts from such heterogeneity.

${ }^{6}$ This Census was also conducted in 1992 and 1997. Unfortunately, the Taxable Property Values in the Census of Governments, which is used to calculate effective unit tax rates in each state, was discontinued after 1987.
} 
representation as an instrument for tax rates, I also exclude Nebraska given its nonpartisan legislature. Finally, I drop the 1982 observation for Wyoming due to apparent data inconsistencies. ${ }^{7}$ Summary statistics and sources for the data are provided in Table 1.

Given its static nature, the theoretical model does not inform as to whether the stock of capital or flow of investment is the appropriate left hand side variable. Therefore, estimates using both measures will be presented. Data on the distribution of manufacturing capital and investment across states are taken from the Census of Manufactures. $^{8}$ Conducted every five years since 1977, this census collects a variety of information from manufacturing establishments, including the gross book value of total depreciable assets, the capital stock measure, and capital expenditures, the investment measure. For both comparability across states and consistency with the theoretical model, capital and investment are normalized according to state population. State population, rather than manufacturing employment, is used for normalization purposes because manufacturing investment normalized by manufacturing employment does not necessarily capture increases in the relative size of the manufacturing sector. States competing for capital are not typically motivated by a desire to increase the capital to labor ratio, but rather by the potential increase in employment and wages resulting from manufacturing investment.

Unfortunately, these capital stock and investment variables have not been collected for other economic sectors, such as mining, agriculture, and services. Manufacturing capital will serve as a valid proxy for total capital in the regression analysis if state business tax levels are independent of variation across states in the sector intensity of economic activity. If states with high tax rates tend to have above-average manufacturing intensities, the responsiveness of capital and investment to taxation will be biased downwards. By contrast, if high-tax states tend to have below-average manufacturing intensities, the responsiveness of capital and investment to taxation will be biased upwards.

As a measure of tax burdens, I attempt to replicate the effective tax rate calculations presented in Wheaton (1983). These unit tax rates are calculated by first adding up all the taxes for which manufactures are legally liable, and then dividing by the manufacturing capital stock, or base. ${ }^{9}$ The numerator consists of three types of state and local government taxes: property taxes, corporate income taxes, and license fees. For each of these sources of revenue, the Census publication State Tax Collections provides state-specific receipts, which must then be partitioned between manufacturing and nonmanufacturing sources. Regarding property taxes, the Taxable Property Values volume in the Census of Governments provides state-specific assessment values for industrial

\footnotetext{
${ }^{7}$ The Wyoming manufacturing capital stock falls over 30 percent from 1977 to 1982 and then increases almost 65 percent between 1982 and 1987.

${ }^{8}$ These data have been used in many studies on investment and state policies, such as Hines (1996).

${ }^{9}$ Of course, the economic incidence may differ from the statutory incidence. For example the burden of unemployment taxes may be borne by labor, rather than capital. Since economic incidence is unobserved, we assume that statutory incidence is a reasonable approximation. Note that the failure to measure economic incidence would only induce measurement error, biasing estimates of investment responsiveness in this paper towards zero.
} 
and non-industrial properties. Wheaton partitions corporate income taxes between manufacturing and non-manufacturing in proportion to measures of state-specific net business income (defined by Wheaton as GSP less employee compensation) in the Bureau of Economic Analysis (BEA) Gross State Product (GSP) accounts. Finally, license fees are partitioned between manufacturing and non-manufacturing according to BEA employment data, which Wheaton considers a proxy for the number of establishments. Although Wheaton also includes unemployment taxes in addition to these three other taxes, unemployment taxes are effectively payroll taxes and are likely borne by labor, rather than capital. Regression results that include unemployment taxes, not reported here, were qualitatively similar to the baseline results.

Since Wheaton provides the effective tax rates for 1977 only, I attempt to replicate the calculations for 1977, 1982, and 1987. Even including unemployment taxes, I was unable to exactly replicate the Wheaton measure for 1977; however, the correlation between my constructed effective tax rates and Wheaton's rates is fairly high, at 0.83.

Since these state tax rates are almost certainly a noisy measure of the true effective tax rate, there is a problem of errors in variables. For example, during recessions, firms will be pushed into lower marginal tax brackets, depressing the effective tax rate measure for purely cyclical reasons. The classic solution to this measurement error problem is to use instruments for the noisy measure. Thus, measurement error in the constructed effective tax rates is an alternative motivation for the use of instrumental variables techniques and provides an alternative explanation for the weak results found in the existing literature.

The theoretical tax competition model does not inform as to which variables should be included in the vector of observable location characteristics $(X)$. Therefore, I simply use measures found in prior studies. High prices of input factors (electricity, natural gas, and land) may dissuade firms from locating in the jurisdiction. Unfortunately, factor demand considerations may cause prices of these factors to increase with capital's propensity to locate in a jurisdiction; thus, these coefficients may be biased towards zero. High rates of unionization may also dissuade firms from locating in a jurisdiction since unions use their bargaining power in order to increase labor costs. The final measure of observable location characteristics is total road mileage in a state, which captures the productivity of public infrastructure and access to transportation systems. All monetary variables are converted into 1987 dollars.

\section{$5 \quad$ Empirical Results}

\subsection{Random Effects Estimates}

The first column of Table 2 provides results from a state random effects estimator of the parameters of equation (10). In these baseline regressions, the stock of capital is employed as the left-hand side variable. Market dummy variables $\left(\lambda_{m}\right)$ for years 1977 and 1982 are also included as right-hand side variables, but are not reported in the table. The coefficient on the effective tax rate is statistically insignificant, and, regarding its magnitude, the corresponding elasticity is below 0.1 , the low end of the range of elastic- 
ities reported by Bartik (1994). As described above, a correlation between unobserved location characteristics and effective tax rates may bias this coefficient towards zero.

As expected, the coefficient on the natural gas prices is negative, although there is a positive coefficient on electricity and land prices. As described above, these positive coefficients may represent a relationship between manufacturing activity and demand for factor inputs. The unionization variable has an unexpected positive sign and is statistically significant. Finally, the road mileage coefficient has the expected positive sign, although this coefficient is small and statistically insignificant.

\subsection{Fixed Effects Estimates}

The second column provides results from a state fixed effects estimator of the parameters of equation (10). The coefficient on the effective tax rate is insignificant and the implied elasticity is low, at 0.02. With the exception of road mileage, the other coefficients are similar in sign and magnitude to those in the random effects estimates. Given this similarity in the parameter estimates, it is not surprising that a Hausman test for fixed or random effects, not reported in Table 2, fails to reject the random effects estimator at either the 5 or 10 percent level.

\subsection{Instrumental Variables Estimates}

To correct for the omitted variable bias demonstrated in the theoretical model, an instrumental variables estimator provides variation in effective tax rates that is independent of unobserved location characteristics. I use the generalized two-stage least squares estimator (G2SLS) due to Balestra and Varadharajan-Krishnakumar (1987), which accounts for the panel nature of the data. See Baltagi (1995) for further details about this instrumental variables estimator.

As instruments for tax rates, the theoretical model motivated the following four measures: state population $(L)$, preferences for public goods, as reflected in the marginal rate of substitution $\left(\frac{\partial U / \partial G}{\partial U / \partial Z}\right)$, costs of providing public goods $(c)$, and characteristics of other jurisdictions, which is reflected in the elasticity of investment with respect to tax rates $(\varepsilon)$. As measures of preferences for public services, I include the proportion of the population under 18 and the proportion over 65 . States with significant young and elderly populations may set above average tax rates in order to finance government programs, such as education and Medicaid, for these groups. Further, while the theoretical model abstracts from tax mix considerations, elderly populations may prefer business taxes to other types of taxes, such as residential property taxes.

The third set of instruments, unit costs of providing public goods, are proxied by the percent of the population living in a metro area, population density, and square miles of the state. These measures capture the fact that public good production costs, such as labor input costs, tend to be higher in urban areas. ${ }^{10}$

\footnotetext{
${ }^{10}$ Estimates of education cost functions typically confirm this hypothesis of higher costs in urban areas. See Imazeki and Reschovsky (2001) and Duncombe et al. (1996).
} 
For the fourth set of instruments, competitor location characteristics, I use the observable characteristics of other states within the state's Census region. Although there is no spatial component in the tax competition model, geographically close states are likely the most relevant competitors. While any combination of these characteristics would serve as valid instrument, we choose to take a simple average across the set of competitors. As a robustness check for this definition of competitors, I also use states sharing a common border.

Finally, although these instruments are not explicitly motivated by the theoretical model, I also include political instruments for tax rates, as suggested for policy analyses by Besley and Case (2000). Particular measures include indicator variables for Democrat-controlled legislatures, Republican-controlled legislatures, and Democrat governors. The Republican Party is often considered both the anti-tax and pro-business party and thus may set lower business tax rates than do Democrat-controlled state governments.

Most of the coefficients on the instruments, as shown in column (3), are statistically insignificant. Legislatures controlled by Republicans set higher tax rates than do Democrat-controlled or divided legislatures. The competitor state measures seem to have the most power. States set lower tax rates in the face of competitors with high natural gas prices and well developed highway systems, but set higher tax rates in the face of competitors with significant rates of unionization. Note that, while these instruments have fairly weak explanatory power for tax rates in this first-stage, this weakness of instruments only biases instrumental variables estimators in the direction of the estimates in the existing literature, which typically assume exogenous variation in tax rates. ${ }^{11}$

The second-stage results, displayed in the fourth column, suggest a responsiveness of capital to business taxation that is larger than that found in the random effects results. The coefficient of -38.9353 corresponds to an elasticity of 0.19 , a measure stronger than that found using both the random and fixed effects estimators. This result demonstrates that a correlation between location characteristics and business tax rates, shown to be non-zero in the tax competition model, masks the true deterrent effects of tax rates on investment location decisions.

\subsection{Robustness Checks}

As a first robustness check, columns (5) and (6) present the results from an instrumental variables estimator that uses the characteristics of neighboring, or border, states, rather than the characteristics of those states within the Census region. Using this alternative definition of competitors, only one of the competitor state instruments, road mileage, is statistically significant. In the second stage, the tax coefficient is similar in magnitude to that in the baseline estimates and is statistically significant at the 5 percent level. The corresponding elasticity in this case is 0.21 , again slightly higher than the baseline results using Census region instruments.

\footnotetext{
${ }^{11}$ See Staiger and Stock (1997) and Bound, Jaeger, and Baker (1995).
} 
Table 3 presents the results using state investment, rather than state capital stocks, as the dependent variable. Investment may be more responsive to tax rate differences, relative to capital stocks, given the fixed costs associated with moving manufacturing plants. Similarly to the capital stock results, the random effects and fixed effects estimates suggest a fairly small elasticity of 0.16 and 0.12 , respectively. The two-stage least squares estimator reports results that are stronger than the capital stock results for both the within-region and neighbor competitor state definitions. The 2SLS investment elasticities of 0.47 and 0.33 are at the mid-to-upper end of the range of elasticities in the survey by Bartik (1994).

Tables 4 and 5 present the results of regressions in which the effect of the three underlying business taxes (property taxes, corporate income taxes, and license fees) was estimated separately. In addition to allowing for a more flexible econometric specification, this analysis of separate effective tax rates has the advantage of allowing one to use separate tax bases for each of the three tax revenue sources. Given that the capital stock serves as a reasonable tax base for both property taxes and license fees, I continue to use the capital stock as the tax base for these two sources. However, for the corporate income tax base, I use BEA's state-specific measure of net business income as a proxy for corporate profits. As shown in Table 4, the coefficients on almost all of the tax rate measures are statistically insignificant when using the capital stock as the dependent variable. The one exception is the coefficient on the property tax rate, which is negative and statistically significant at the 10 percent level in the G2SLS specification in which characteristics of neighboring states are used as instruments. The results using investment as the dependent variable are stronger. As shown in Table 5, the coefficient on property tax rates is negative and statistically significant in three of the four specifications, and the coefficient on license fee rates is statistically significant in the fixed effects estimates.

\section{Welfare Analysis}

This section uses the elasticity estimates from the previous section, along with a convenient specification of a resident utility function over public and private goods, in order to calculate the degree of undertaxation of capital associated with the failure of jurisdictions to internalize the external effects of tax rate choices. While the theoretical tax competition literature has focused almost exclusively on this normative issue, it has yet to be addressed in the empirical literature, which has had a primarily positive focus. For the purposes of this welfare calculation, consider a quasilinear form for resident utility over private and public goods:

$$
U(z, G)=z+\gamma \log (G)
$$

where $\gamma$ represents the preference intensity for public goods, relative to private goods. Using this functional form, one can express the modified Samuelson condition, given by equation (7), as follows: 


$$
L \frac{\gamma}{G}=\frac{c}{1-\varepsilon}
$$

The unmodified, or true, Samuelson condition for public good provision $\left(G^{S}\right)$ is given below:

$$
L \frac{\gamma}{G^{S}}=c
$$

According to this familiar rule, the sum of willingnesses to pay for public goods across state residents is set equal to the marginal cost of provision $(c)$. Under the modified Samuelson rule, when deciding whether to lower tax rates, jurisdictions fail to internalize the tax base benefits for residents of neighboring jurisdictions, leading to the undertaxation of capital, as captured by the term $(1-\varepsilon)$. In the case of a zero elasticity, national and regional interests align, and each jurisdiction acting in isolation sets efficient tax rates.

One measure of the degree of this underprovision is the ratio of revenues under tax competition to Samuelson revenues $\left(G / G^{S}\right)$. Using equations (12) and (13) above, one can express this under-taxation ratio as follows:

$$
\frac{G}{G^{S}}=1-\varepsilon
$$

This measure, which is less than or equal to unity, is decreasing in the elasticity of investment with respect to the effective tax rate. As described above, the measure equals unity in the special case of a zero elasticity, or complete lack of investment response to tax rate differentials, because there are no externalities in this case.

Using the elasticity estimates from Tables 2 and 3 of the previous section, Table 6 provides estimates of the degree of undertaxation for each of the estimators. The undertaxation ratio varies significantly, from 0.53 to 0.98 . These ratios are lower for the results using investment flows, rather than capital stocks, as the dependent variable. This difference is not unexpected given that the flow of investment can be re-directed to low-tax jurisdictions much more easily than can the stock of capital.

It is important to note two limitations of this welfare analysis. First, these results do not explicitly prove that state governments under-tax manufacturing investment. Rather, this analysis should be interpreted under the maintained hypothesis that the tax competition model is correctly specified. Said differently, I have estimated the key parameters of the tax competition model, rather than tested it against a well-defined alternative. In dynamic models, the optimal tax rate on capital is often zero; see Auerbach and Hines (2002). Second, while the tax competition model assumes that states have access only to manufacturing capital taxes, such taxes are a relatively small share of total state tax revenues. To the extent that, in the face of mobile tax bases, states simply shift to less distortionary tax bases, this analysis may over-state the degree of under-provision of public goods. In this case, these results should be considered as an upper-bound on the degree of under-taxation. 


\section{Conclusion}

Using insights from theoretical models of tax competition, this paper makes four separate contributions to the empirical literature on tax competition. The first contribution involves the endogeneity of tax rates. While the empirical literature has often assumed the exogeneity of taxes, the theoretical literature shows that these tax rates are not set in a vacuum. Rather, this theoretical literature, which has focused on the competition between jurisdictions for capital, demonstrates that tax rates and investment decisions are interrelated and are both driven by the same set of jurisdiction characteristics. This endogeneity of tax rates may explain the relatively weak elasticity estimates found in the existing literature. In order to correct for such endogeneity, the tax competition model motivates instruments based upon four factors: resident preferences for public goods, costs of providing public goods, state population, and characteristics of competitor, or neighbor, states. These endogeneity corrected estimates report elasticities at the upper end of the range of elasticities in the existing literature, while the uncorrected estimates report elasticities at the lower end of this range.

The second contribution involves the appropriate unit of observation. The existing empirical literature has employed both discrete choice analyses, in which plants are the unit of observation, and aggregated analyses, in which jurisdictions are the unit of observation. The theoretical model demonstrates that a key assumption in empirical discrete choice analyses, independence of location choices, is violated. By contrast, estimating equations in aggregated models can be derived directly from a simple noarbitrage condition, or equalization of after-tax rates of return, in the tax competition model.

Third, the theoretical model demonstrates that the effective tax rate, rather than the after-tax rate of return, is the appropriate measure of business tax burdens. In the tax competition model, the after-tax rate of return, which has been often employed in the existing empirical literature, is both invariant across jurisdictions and endogenous, or dependent upon the distribution of investment across states. Following this guidance, state-specific measures of effective tax rates similar to those suggested by Wheaton (1983) are constructed and employed in the empirical analysis.

The fourth empirical contribution involves the normative properties of capital tax competition. While these properties have been studied extensively in the theoretical tax competition literature, they have yet to be addressed empirically. In the tax competition model, states set tax rates according to a modified Samuelson condition. According to this rule, when determining tax rates that maximize resident utilities, jurisdictions fail to internalize the tax base effects for residents of other jurisdictions. Thus, from a national perspective, each jurisdiction acting in isolation sets tax rates on capital that are too low. Using the endogeneity corrected elasticity estimates and a convenient specification for resident utility functions, I attempt to uncover the Samuelson revenues. These calculations suggest that, in the context of this static tax competition model, the efficient revenues can be as much as two times the size of the actual, or observed, revenues. 


\section{References}

[1] Alan Auerbach and James Hines. Taxation and economic efficiency. In A. Auerbach and M. Feldstein, editors, Handbook of Public Economics, Vol III. Amstredam: New Holland, 2002.

[2] P. Balestra and J. Varadharajan-Krishnakumar. Full information estimations of a system of simultaneous equations with error components structure. Econometric Theory, 3:223-246, 1987.

[3] Badi Baltagi. Econometric Analysis of Panel Data. John Wiley and Sons, West Sussex, 1995.

[4] Timothy Bartik. Taxes and local economic development: What do we know and how do we know it. Proceedings of the Eighty-Seventh Annual Conference on Taxation, pages 102-106, 1994.

[5] Timothy Besley and Ann Case. Unnatural experiments? estimating the incidence of endogenous policies. Econmic Journal, 112, 2000.

[6] John Bound, David A. Jaeger, and Regina M. Baker. Problems with instrumental variables estimation when the correlation between the instruments and the endogenous explanatory variable is weak. Journal of the American Statistical Association, 90:443-450, 1995.

[7] D. Carlton. The location and employment choices of new firms: An econometric model with discrete and continuous endogenous variables. Review of Economics and Statistics, 65, 1983.

[8] William Duncombe, John Ruggiero, and John Yinger. Alternative approaches to measuring the cost of education. In Helen F. Ladd, editor, Holding School Accountable: Performance-Based Reform in Education. Brookings Institution, 1996.

[9] James Hines. Altered states: Taxes and the location of foreign direct investment. American Economic Review, 86, 1996.

[10] Jennifer Imazeki and Andrew Reschovsky. Achieving educational adequacy through school finance reform,. Journal of Education Finance, 26, 2001.

[11] Wallace Oates. Fiscal Federalism. Harcourt Brace, New York, 1972.

[12] Wallace Oates. An essay on fiscal federalism. Journal of Economic Literature, 37, 1999.

[13] Leslie Papke. Subnational taxation and capital mobility: Estimates of tax price elasticities. National Tax Journal, 40:191-203, 1987.

[14] Leslie Papke. Interstate business differentials and new firm location: Evidence from panel data. Journal of Public Economics, 45, 1991. 
[15] Douglas Staiger and James Stock. Instrumental variables regressions with weak instruments. Econometrica, 65, 1997.

[16] M. Wasylenko. Taxation and economic development: the state of the economic literature. New England Economic Review, pages 37-52, 1997.

[17] William Wheaton. Interstate differences in the level of business taxation. National Tax Journal, 36:83-94, 1983.

[18] D. Wildasin. Interjurisdictional capital mobility: Fiscal externality and a corrective subsidy. Journal of Urban Economics, 25, 1989.

[19] John Wilson. A theory of interregional tax competition. Journal of Urban Economics, 19, 1986.

[20] John Wilson. Theories of tax competition. National Tax Journal, 52, 1999.

[21] G. Zodrow and P. Mieszkowski. Pigou, tiebout, property taxation and the underprovision of local public goods. Journal of Urban Economics, 19, 1986. 
Table 1

Summary Statistics, 47 states $(1977,1982,1987)$

\begin{tabular}{|c|c|c|c|}
\hline variable & $\begin{array}{l}\text { average } \\
\text { (std. dev) }\end{array}$ & description & source \\
\hline \multicolumn{4}{|l|}{ key measures } \\
\hline $\begin{array}{l}\text { per-capita } \\
\text { capital stock }\end{array}$ & $\begin{array}{r}\$ 3.5403 \\
(1.3972)\end{array}$ & $\begin{array}{l}\text { manufacturing capital }(\$ 1,000 \mathrm{~s}) \\
\text { per state resident }\end{array}$ & Census of Manufactures \\
\hline $\begin{array}{l}\text { per-capita } \\
\text { investment }\end{array}$ & $\begin{array}{r}\$ 0.3698 \\
(0.1639)\end{array}$ & $\begin{array}{l}\text { manufacturing investment }(\$ 1,000 \mathrm{~s}) \\
\text { per state resident }\end{array}$ & Census of Manufactures \\
\hline effective tax rate & $\begin{array}{r}0.0173 \\
(0.0107)\end{array}$ & $\begin{array}{l}\text { manufacturing tax collections } \\
\text { per capital stock }\end{array}$ & Constructed \\
\hline \multicolumn{4}{|c|}{ location characteristics } \\
\hline electricity price & $\begin{array}{r}0.0150 \\
(0.0042)\end{array}$ & $\begin{array}{l}\text { electricity price per million BTU } \\
\text { industrial sector }(\$ 1,000 \mathrm{~s})\end{array}$ & $\begin{array}{l}\text { State Energy Price and } \\
\text { Expenditure Report } 1995\end{array}$ \\
\hline natural gas price & $\begin{array}{r}0.0039 \\
(0.0013)\end{array}$ & $\begin{array}{l}\text { natural gas price per million BTU } \\
\text { industrial sector }(\$ 1,000 \mathrm{~s})\end{array}$ & $\begin{array}{l}\text { State Energy Price and } \\
\text { Expenditure Report } 1995\end{array}$ \\
\hline land price & $\begin{array}{r}0.0142 \\
(0.0104)\end{array}$ & value of farm land per acre & $\begin{array}{l}\text { Economic Research } \\
\text { Service (USDA) }\end{array}$ \\
\hline$\%$ unionized & $\begin{array}{r}0.1549 \\
(0.0743)\end{array}$ & $\begin{array}{l}\text { percent of private } \\
\text { workforce unionized }\end{array}$ & $\begin{array}{l}\text { Union Membership and } \\
\text { Earnings Data Book }\end{array}$ \\
\hline road mileage & $\begin{array}{r}0.0803 \\
(0.0482) \\
\end{array}$ & $\begin{array}{l}\text { total rural and urban } \\
\text { highway miles (millions) }\end{array}$ & $\begin{array}{l}\text { FHA Highway } \\
\text { Statistics Series }\end{array}$ \\
\hline \multicolumn{4}{|l|}{ instruments } \\
\hline total population & $\begin{array}{r}4.8474 \\
(4.917)\end{array}$ & state population & $\begin{array}{l}\text { Statistical Abstract } \\
\text { of the United States }\end{array}$ \\
\hline $\begin{array}{l}\% \text { population } \\
<\text { age } 18\end{array}$ & $\begin{array}{r}0.2068 \\
(0.0222)\end{array}$ & $\begin{array}{l}\text { proportion of population } \\
\text { under age } 18\end{array}$ & $\begin{array}{l}\text { Statistical Abstract } \\
\text { of the United States }\end{array}$ \\
\hline $\begin{array}{l}\% \text { population } \\
>\text { age } 65\end{array}$ & $\begin{array}{r}0.1153 \\
(0.0186)\end{array}$ & $\begin{array}{l}\text { proportion of population } \\
\text { over age } 65\end{array}$ & $\begin{array}{l}\text { Statistical Abstract } \\
\text { of the United States }\end{array}$ \\
\hline $\begin{array}{l}\% \text { population } \\
\text { metro area }\end{array}$ & $\begin{array}{r}0.6152 \\
(0.2365)\end{array}$ & $\begin{array}{l}\text { proportion of population } \\
\text { residing in metro area }\end{array}$ & $\begin{array}{l}\text { Statistical Abstract } \\
\text { of the United States }\end{array}$ \\
\hline $\begin{array}{l}\text { population } \\
\text { density }\end{array}$ & $\begin{array}{r}163.3023 \\
(228.5484)\end{array}$ & population per square mile & constructed \\
\hline square miles & $\begin{array}{r}61.2873 \\
(47.0961) \\
\end{array}$ & state square miles & $\begin{array}{l}\text { Statistical Abstract } \\
\text { of the United States }\end{array}$ \\
\hline $\begin{array}{l}\text { Democrat } \\
\text { governor }\end{array}$ & $\begin{array}{r}0.6357 \\
(0.4830) \\
\end{array}$ & indicator for Democrat governor & Book of the States \\
\hline $\begin{array}{l}\text { Democrat } \\
\text { legislature }\end{array}$ & $\begin{array}{r}0.2071 \\
(0.4067)\end{array}$ & $\begin{array}{l}\text { indicator for both chambers } \\
\text { controlled by Democrats }\end{array}$ & Book of the States \\
\hline $\begin{array}{l}\text { Republican } \\
\text { legislature }\end{array}$ & $\begin{array}{r}0.6214 \\
(0.4868)\end{array}$ & $\begin{array}{l}\text { indicator for both chambers } \\
\text { controlled by Republicans }\end{array}$ & Book of the States \\
\hline
\end{tabular}




\begin{tabular}{|c|c|c|c|c|c|c|}
\hline \multicolumn{7}{|c|}{$\begin{array}{l}\text { Table 2: Capital and Taxes } \\
{ }^{* *} \text { denotes } 95 \text { percent significance, }{ }^{*} \mathrm{~d}\end{array}$} \\
\hline & $\mathrm{RE}$ & $\mathrm{FE}$ & G2SLS & G2SLS & G2SLS & G2SLS \\
\hline dep. variable & capital & capital & tax rate & capital & tax rate & capital \\
\hline competitor defn. & & & region & region & neighbors & neighbors \\
\hline effective tax rate & $\begin{array}{l}-11.1099 \\
(7.9733)\end{array}$ & $\begin{array}{l}-4.4316 \\
(8.6972)\end{array}$ & & $\begin{array}{l}-38.9353^{* *} \\
(19.2448)\end{array}$ & & $\begin{array}{l}-42.0132^{* *} \\
(21.2534)\end{array}$ \\
\hline electricity price & $\begin{array}{l}14.7164 \\
(23.1258)\end{array}$ & $\begin{array}{l}27.8905 \\
(25.9374)\end{array}$ & $\begin{array}{l}-0.1663 \\
(0.2896)\end{array}$ & $\begin{array}{l}6.6189 \\
(24.7354)\end{array}$ & $\begin{array}{l}-0.3013 \\
(0.2888)\end{array}$ & $\begin{array}{l}4.7591 \\
(25.2157)\end{array}$ \\
\hline natural gas price & $\begin{array}{l}-33.8343 \\
(59.1090)\end{array}$ & $\begin{array}{l}-16.2120 \\
(63.3509)\end{array}$ & $\begin{array}{l}-0.6464 \\
(0.8070)\end{array}$ & $\begin{array}{l}-13.1780 \\
(62.3435)\end{array}$ & $\begin{array}{l}0.2268 \\
(0.7220)\end{array}$ & $\begin{array}{l}-10.0481 \\
(64.1541)\end{array}$ \\
\hline land price & $\begin{array}{l}22.6073^{* *} \\
(9.6705)\end{array}$ & $\begin{array}{l}20.1804^{*} \\
(11.0076)\end{array}$ & $\begin{array}{l}-0.2027 \\
(0.1314)\end{array}$ & $\begin{array}{l}22.8352^{* *} \\
(10.0643)\end{array}$ & $\begin{array}{l}-0.0440 \\
(0.1365)\end{array}$ & $\begin{array}{l}23.4844^{* *} \\
(10.2233)\end{array}$ \\
\hline$\%$ unionized & $\begin{array}{l}4.0040^{* *} \\
(1.6297)\end{array}$ & $\begin{array}{l}3.6860^{*} \\
(1.8768)\end{array}$ & $\begin{array}{l}0.0338^{*} \\
(0.0203)\end{array}$ & $\begin{array}{l}4.6515^{* *} \\
(1.7458)\end{array}$ & $\begin{array}{l}0.0235 \\
(0.0194)\end{array}$ & $\begin{array}{l}4.7265^{* *} \\
(1.7798)\end{array}$ \\
\hline road mileage & $\begin{array}{l}0.1723 \\
(3.4942)\end{array}$ & $\begin{array}{l}-8.9364 \\
(7.4735)\end{array}$ & $\begin{array}{l}-0.0174 \\
(0.0620)\end{array}$ & $\begin{array}{l}-0.5313 \\
(3.7676)\end{array}$ & $\begin{array}{l}-0.0102 \\
(0.0584)\end{array}$ & $\begin{array}{l}-0.3724 \\
(3.7090)\end{array}$ \\
\hline total population & & & $\begin{array}{l}-0.0003 \\
(0.0005)\end{array}$ & & $\begin{array}{l}-0.0004 \\
(0.0005)\end{array}$ & \\
\hline $\begin{array}{l}\% \text { population } \\
<\text { age } 18\end{array}$ & & & $\begin{array}{l}0.0481 \\
(0.0685)\end{array}$ & & $\begin{array}{l}0.0145 \\
(0.0698)\end{array}$ & \\
\hline $\begin{array}{l}\% \text { population } \\
>\text { age } 65\end{array}$ & & & $\begin{array}{l}0.0206 \\
(0.1026)\end{array}$ & & $\begin{array}{l}-0.0270 \\
(0.0996)\end{array}$ & \\
\hline $\begin{array}{l}\% \text { population } \\
\text { metro area }\end{array}$ & & & $\begin{array}{l}0.0116 \\
(0.0089)\end{array}$ & & $\begin{array}{l}0.0086 \\
(0.0086)\end{array}$ & \\
\hline $\begin{array}{l}\text { population } \\
\text { density }\end{array}$ & & & $\begin{array}{l}0.00002 \\
(0.00001)\end{array}$ & & $\begin{array}{l}0.00002 \\
(0.00001)\end{array}$ & \\
\hline square miles & & & $\begin{array}{l}0.00001 \\
(0.0007)\end{array}$ & & $\begin{array}{l}0.00005 \\
(0.00006)\end{array}$ & \\
\hline $\begin{array}{l}\text { Democrat } \\
\text { governor }\end{array}$ & & & $\begin{array}{l}0.0008 \\
(0.0010)\end{array}$ & & $\begin{array}{l}0.0004 \\
(0.0010)\end{array}$ & \\
\hline $\begin{array}{l}\text { Democrat } \\
\text { legislature }\end{array}$ & & & $\begin{array}{l}0.0012 \\
(0.0014)\end{array}$ & & $\begin{array}{l}0.0011 \\
(0.0015)\end{array}$ & \\
\hline $\begin{array}{l}\text { Republican } \\
\text { legislature }\end{array}$ & & & $\begin{array}{l}0.0055^{* *} \\
(0.0016)\end{array}$ & & $\begin{array}{l}0.0040^{* *} \\
(0.0017)\end{array}$ & \\
\hline $\begin{array}{l}\text { competitor } \\
\text { electricity price }\end{array}$ & & & $\begin{array}{l}0.1529 \\
(0.8858)\end{array}$ & & $\begin{array}{l}-0.0230 \\
(0.5862)\end{array}$ & \\
\hline $\begin{array}{l}\text { competitor } \\
\text { natural gas price }\end{array}$ & & & $\begin{array}{l}-10.3375^{* *} \\
(4.5154)\end{array}$ & & $\begin{array}{l}-1.8216 \\
(1.3135)\end{array}$ & \\
\hline $\begin{array}{l}\text { competitor } \\
\text { land price }\end{array}$ & & & $\begin{array}{l}-0.6484 \\
(0.4343)\end{array}$ & & $\begin{array}{l}-0.3135 \\
(0.2209)\end{array}$ & \\
\hline $\begin{array}{l}\text { competitor } \\
\% \text { unionized }\end{array}$ & & & $\begin{array}{l}0.2665^{* *} \\
(0.1018)\end{array}$ & & $\begin{array}{l}0.0223 \\
(0.0307)\end{array}$ & \\
\hline $\begin{array}{l}\text { competitor } \\
\text { road mileage }\end{array}$ & & & $\begin{array}{l}-0.4793^{* *} \\
(0.1760)\end{array}$ & & $\begin{array}{l}-0.1688^{* *} \\
(0.0811)\end{array}$ & \\
\hline
\end{tabular}




\begin{tabular}{|c|c|c|c|c|c|c|}
\hline \multicolumn{7}{|c|}{$\begin{array}{l}\text { Table 3: Investment and Taxes } \\
\left(* * \text { denotes } 95 \text { percent significance, }{ }^{*} \text { denotes } 90 \text { percent significance }\right)\end{array}$} \\
\hline & $\mathrm{RE}$ & $\mathrm{FE}$ & G2SLS & G2SLS & G2SLS & G2SLS \\
\hline dep. variable & investment & investment & tax rate & investment & tax rate & investment \\
\hline competitor defn. & & & region & region & neighbors & neighbors \\
\hline effective tax rate & $\begin{array}{l}-3.4614^{* *} \\
(1.5466)\end{array}$ & $\begin{array}{l}-2.5570 \\
(2.2367)\end{array}$ & & $\begin{array}{l}-10.1196^{* *} \\
(3.7635)\end{array}$ & & $\begin{array}{l}-6.9994^{* *} \\
(3.1486)\end{array}$ \\
\hline electricity price & $\begin{array}{l}-0.4990 \\
(4.5109)\end{array}$ & $\begin{array}{l}0.0105 \\
(6.6703)\end{array}$ & $\begin{array}{l}-0.1391 \\
(0.3025)\end{array}$ & $\begin{array}{l}-0.6151 \\
(4.9072)\end{array}$ & $\begin{array}{l}-0.3483 \\
(0.2884)\end{array}$ & $\begin{array}{l}-0.5693 \\
(4.6244)\end{array}$ \\
\hline natural gas price & $\begin{array}{l}-2.6734 \\
(13.4885)\end{array}$ & $\begin{array}{l}1.5753 \\
(16.2919)\end{array}$ & $\begin{array}{l}-0.1764 \\
(0.8756)\end{array}$ & $\begin{array}{l}4.9999 \\
(14.9141)\end{array}$ & $\begin{array}{l}0.3209 \\
(0.8014)\end{array}$ & $\begin{array}{l}2.0583 \\
(14.2510)\end{array}$ \\
\hline land price & $\begin{array}{l}3.7459^{* *} \\
(1.8746)\end{array}$ & $\begin{array}{l}2.3485 \\
(2.8308)\end{array}$ & $\begin{array}{l}-0.1158 \\
(0.1436)\end{array}$ & $\begin{array}{l}3.9643^{*} \\
(2.0507)\end{array}$ & $\begin{array}{l}0.0525 \\
(0.1438)\end{array}$ & $\begin{array}{l}3.9391^{* *} \\
(1.9317)\end{array}$ \\
\hline$\%$ unionized & $\begin{array}{l}0.3224 \\
(0.2848)\end{array}$ & $\begin{array}{l}0.4610 \\
(0.4827)\end{array}$ & $\begin{array}{l}0.0420^{* *} \\
(0.0180)\end{array}$ & $\begin{array}{l}0.5306 \\
(0.3285)\end{array}$ & $\begin{array}{l}0.0451^{* *} \\
(0.0177)\end{array}$ & $\begin{array}{l}0.4257 \\
(0.3024)\end{array}$ \\
\hline road mileage & $\begin{array}{l}0.2597 \\
(0.4301)\end{array}$ & $\begin{array}{l}-4.4944^{* *} \\
(1.9220)\end{array}$ & $\begin{array}{l}-0.0506 \\
(0.0532)\end{array}$ & $\begin{array}{l}0.0773 \\
(0.4980)\end{array}$ & $\begin{array}{l}-0.0519 \\
(0.0436)\end{array}$ & $\begin{array}{l}0.1883 \\
(0.4492)\end{array}$ \\
\hline total population & & & $\begin{array}{l}0.0001 \\
(0.0004)\end{array}$ & & $\begin{array}{l}0.0001 \\
(0.0004)\end{array}$ & \\
\hline $\begin{array}{l}\% \text { population } \\
<\text { age } 18\end{array}$ & & & $\begin{array}{l}-0.0167 \\
(0.0727)\end{array}$ & & $\begin{array}{l}-0.0581 \\
(0.0707)\end{array}$ & \\
\hline $\begin{array}{l}\% \text { population } \\
>\text { age } 65\end{array}$ & & & $\begin{array}{l}0.0201 \\
(0.0791)\end{array}$ & & $\begin{array}{l}0.0234 \\
(0.0743)\end{array}$ & \\
\hline $\begin{array}{l}\% \text { population } \\
\text { metro area }\end{array}$ & & & $\begin{array}{l}-0.0043 \\
(0.0072)\end{array}$ & & $\begin{array}{l}-0.0071 \\
(0.0066)\end{array}$ & \\
\hline $\begin{array}{l}\text { population } \\
\text { density }\end{array}$ & & & $\begin{array}{l}0.00002^{* *} \\
(0.00001)\end{array}$ & & $\begin{array}{l}0.00001 \\
(0.00001)\end{array}$ & \\
\hline square miles & & & $\begin{array}{l}0.00006 \\
(0.00005)\end{array}$ & & $\begin{array}{l}0.00009^{* *} \\
(0.00003)\end{array}$ & \\
\hline $\begin{array}{l}\text { Democrat } \\
\text { governor }\end{array}$ & & & $\begin{array}{l}0.0008 \\
(0.0011)\end{array}$ & & $\begin{array}{l}0.0002 \\
(0.0012)\end{array}$ & \\
\hline $\begin{array}{l}\text { Democrat } \\
\text { legislature }\end{array}$ & & & $\begin{array}{l}0.0013 \\
(0.0016)\end{array}$ & & $\begin{array}{l}0.0011 \\
(0.0016)\end{array}$ & \\
\hline $\begin{array}{l}\text { Republican } \\
\text { legislature }\end{array}$ & & & $\begin{array}{l}0.0047^{* *} \\
(0.0019)\end{array}$ & & $\begin{array}{l}0.0036^{*} \\
(0.0019)\end{array}$ & \\
\hline $\begin{array}{l}\text { competitor } \\
\text { electricity price }\end{array}$ & & & $\begin{array}{l}0.2537 \\
(0.9638)\end{array}$ & & $\begin{array}{l}0.6525 \\
(0.5400)\end{array}$ & \\
\hline $\begin{array}{l}\text { competitor } \\
\text { natural gas price }\end{array}$ & & & $\begin{array}{l}-7.8916^{*} \\
(4.5286)\end{array}$ & & $\begin{array}{l}-0.7725 \\
(1.3734)\end{array}$ & \\
\hline $\begin{array}{l}\text { competitor } \\
\text { land price }\end{array}$ & & & $\begin{array}{l}-0.4432 \\
(0.4352)\end{array}$ & & $\begin{array}{l}-0.2937 \\
(0.2104)\end{array}$ & \\
\hline $\begin{array}{l}\text { competitor } \\
\% \text { unionized }\end{array}$ & & & $\begin{array}{l}0.1998^{* *} \\
(0.0871)\end{array}$ & & $\begin{array}{l}-0.0036 \\
(0.0270)\end{array}$ & \\
\hline $\begin{array}{l}\text { competitor } \\
\text { road mileage }\end{array}$ & & & $\begin{array}{l}-0.3432^{* *} \\
(0.1462)\end{array}$ & & $\begin{array}{l}-0.1821^{* *} \\
(0.0545)\end{array}$ & \\
\hline
\end{tabular}


Table 4: Capital and Types of Taxes

(** denotes 95 percent significance, ${ }^{*}$ denotes 90 percent significance)

\begin{tabular}{|l|l|l|l|l|}
\hline estimator & $\mathrm{RE}$ & $\mathrm{FE}$ & G2SLS & G2SLS \\
\hline competitor defn. & & & region & neighbor \\
\hline property tax rate & -12.0439 & -3.8360 & -32.0635 & $-44.0943^{*}$ \\
& $(8.2259)$ & $(8.8488)$ & $(22.3350)$ & $(25.3404)$ \\
\hline corporate income tax rate & 14.8889 & 15.2061 & 10.5903 & 0.4426 \\
& $(11.0619)$ & $(11.2141)$ & $(25.2439)$ & $(29.9403)$ \\
\hline license fee rate & 159.0139 & -103.3480 & 754.6448 & 915.5250 \\
& $(113.7945)$ & $(184.3489)$ & $(581.9212)$ & $(682.0437)$ \\
\hline
\end{tabular}

\section{Table 5: Investment and Types of Taxes}

(** denotes 95 percent significance, ${ }^{*}$ denotes 90 percent significance)

\begin{tabular}{|l|l|l|l|l|}
\hline estimator & RE & FE & G2SLS & G2SLS \\
\hline competitor defn. & & & region & neighbor \\
\hline property tax rate & $-3.5484^{* *}$ & -1.8384 & $-10.3326^{* *}$ & $-7.3882^{*}$ \\
& $(1.6059)$ & $(2.2309)$ & $(4.8247)$ & $(3.9420)$ \\
\hline corporate income tax rate & 1.4185 & 0.2264 & 2.3022 & -0.7797 \\
& $(2.4997)$ & $(2.8272)$ & $(6.7549)$ & $(9.3185)$ \\
\hline license fee rate & 2.5045 & $-113.4472^{* *}$ & -19.0729 & 127.2818 \\
& $(15.5390)$ & $(46.4765)$ & $(85.8732)$ & $(84.7925)$ \\
\hline
\end{tabular}

Table 6: Tax competition and the Degree of Under-taxation

\begin{tabular}{|l|l|l|l|l|}
\hline estimator & RE & FE & G2SLS & G2SLS \\
\hline competitor defn. & & & region & neighbor \\
\hline dependent variable: capital stock & 0.9457 & 0.9783 & 0.8097 & 0.7947 \\
\hline dependent variable: investment & 0.8381 & 0.8804 & 0.5266 & 0.6726 \\
\hline
\end{tabular}

